\title{
A Hydrophobic Small Protein, BpOF4_01690, Is Critical for Alkaliphily of Alkaliphilic Bacillus pseudofirmus OF4
}

\author{
Tetsuaki Takahashi', Terry A. Krulwich ${ }^{2}$ and Masahiro Ito ${ }^{1,3 *}$ \\ ${ }^{1}$ Graduate School of Life Sciences, Toyo University, Gunma, Japan, ${ }^{2}$ Department of Pharmacological Sciences, Icahn \\ School of Medicine at Mount Sinai, New York, NY, United States, ${ }^{3}$ Bio-Nano Electronics Research Centre, Toyo University, \\ Kawagoe, Japan
}

\section{OPEN ACCESS}

Edited by: Philippe M. Oger, UMR5240 Microbiologie, Adaptation et Pathogenie (MAP), France

Reviewed by:

James A. Coker,

University of Maryland University College, United States

Dong-Woo Lee

Yonsei University, South Korea Satyanarayana Tulasi, University of Delhi, India

*Correspondence: Masahiro lto masahiro.ito@toyo.jp

Specialty section: This article was submitted to Extreme Microbiology, a section of the journal Frontiers in Microbiology

Received: 01 May 2018 Accepted: 08 August 2018

Published: 28 August 2018

Citation:

Takahashi T, Krulwich TA and Ito M (2018) A Hydrophobic Small Protein, BpOF4_01690, Is Critical for Alkaliphily of Alkaliphilic Bacillus pseudofirmus OF4.

Front. Microbiol. 9:1994. doi: 10.3389/fmicb.2018.01994
A monocistronic small protein, BpOF4_01690, was annotated in alkaliphilic Bacillus pseudofirmus OF4. It comprises 59 amino acids and is hydrophobic. Importantly, homologs of this protein were identified only in alkaliphiles. In this study, a mutant with a BpOF4_01690 gene deletion (designated $\Delta 01690$ ) exhibited weaker growth than that of the wild type in both malate-based defined and glucose-based defined media under low-sodium conditions at $\mathrm{pH}$ 10.5. Additionally, the enzymatic activity of the respiratory chain of $\Delta 01690$ was much lower than that of the wild type. These phenotypes were similar to those of a ctaD deletion mutant and an atpB- $F$ deletion mutant. Therefore, we hypothesize that BpOF4_01690 plays a critical role in oxidative phosphorylation under highly alkaline conditions.

\section{Keywords: alkaliphiles, small protein, Bacillus pseudofirmus, respiratory chain, pH homeostasis, alkaliphily}

\section{INTRODUCTION}

Alkaliphilic microorganisms usually grow vigorously in highly alkaline environments and require $\mathrm{Na}^{+}$for their growth (Horikoshi, 1991; Krulwich et al., 2011; Preiss et al., 2015). $\mathrm{Na}^{+}$cycling was found to be critical for the alkaline $\mathrm{pH}$ adaptation of alkaliphilic bacteria (Ito et al., 2004a,b) (Figure 1). Although it is extremely difficult to produce and utilize a proton-motive force (PMF) at highly alkaline $\mathrm{pH}$, ATP synthesis by oxidative phosphorylation (OXPHOS) using $\mathrm{F}_{1} \mathrm{~F}_{\mathrm{o}}$-ATP synthase is driven by PMF in alkaliphilic Bacillus species (Guffanti and Krulwich, 1994). Therefore, some effective ATP synthesis mechanisms are expected to operate in these bacteria in their highly alkaline environment. It has been suggested that accumulation of protons on the outer surface of the cytoplasmic membrane (Yoshimune et al., 2010) facilitates energy coupling that is more efficient than usual, thereby increasing the feasibility of ATP synthesis in a highly alkaline pH environment (Krulwich, 1995). The alkaliphilic Bacillus clarkia K24-1U was also proposed to efflux protons by the respiratory chain, accumulating them on the outer surface of the cytoplasmic membrane (Cherepanov et al., 2003; Mulkidjanian, 2006). Another possibility is the activity of an unidentified proton carrier that depends on the dielectric properties of the membrane potential (Liu et al., 2007). Thus, the outer surface vicinity of the cytoplasmic membrane is locally acidified, and enough PMF necessary for the synthesis of ATP is provided despite the alkaline environment. Fast cardiolipin-mediated proton translocation from the respiratory chain pumps to ATP synthase by OXPHOS was also hypothesized. However, the mutational loss of membrane cardiolipin did not significantly affect alkaliphile ATP synthesis in alkaliphilic B. pseudofirmus OF4 (Liu et al., 2014). 


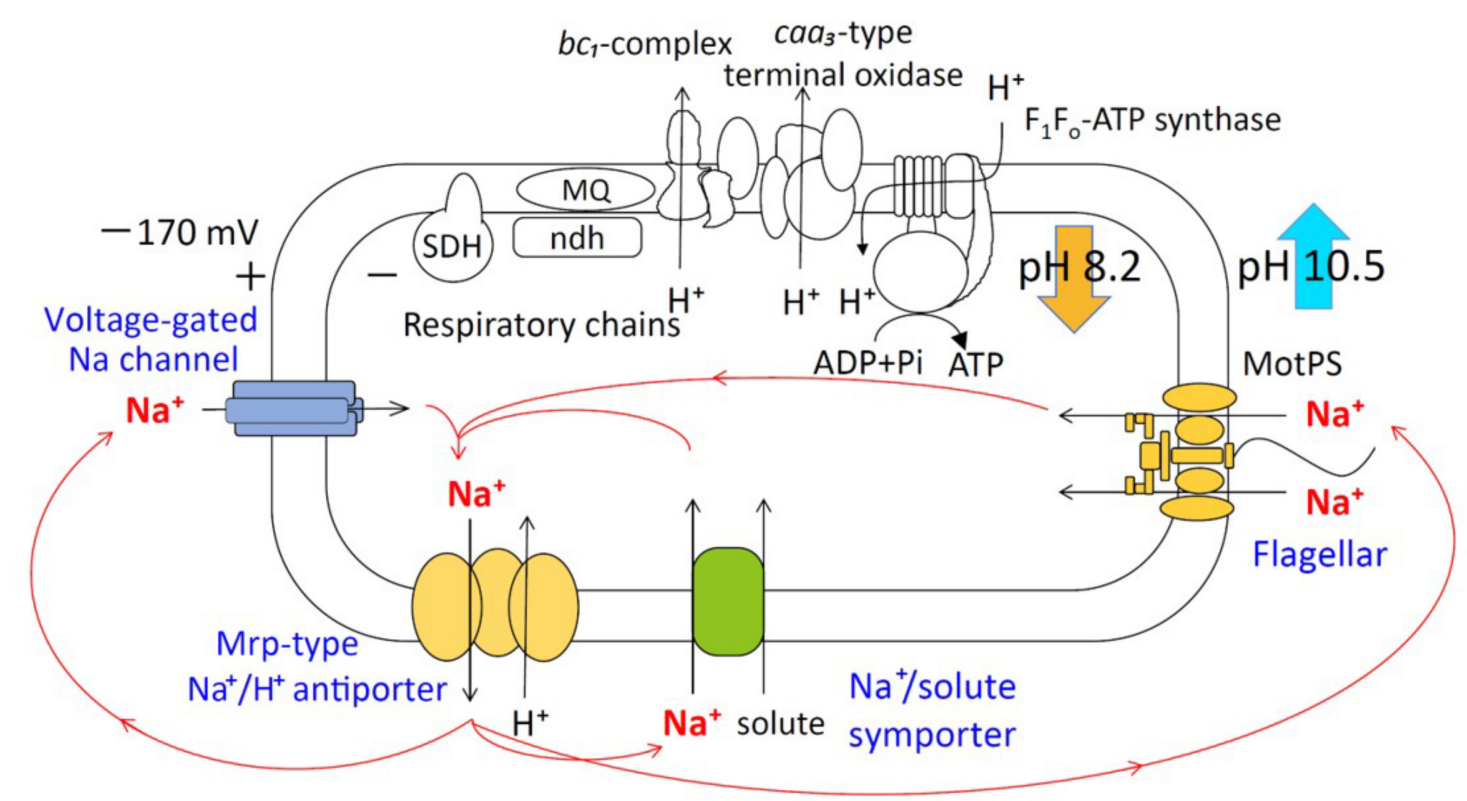

FIGURE 1 | Schematic diagram of the $\mathrm{Na}^{+}$cycle of alkaliphilic Bacillus pseudofirmus OF4. Alkaliphilic B. pseudofirmus OF4 grows well around pH 10, and the intracellular $\mathrm{pH}$ is maintained around 8.2. The Mrp-type $\mathrm{Na}^{+} / \mathrm{H}^{+}$antiporter performs a crucial role in the maintenance of intracellular ion concentrations and $\mathrm{pH}$ homeostasis. $\mathrm{Na}^{+} / \mathrm{H}^{+}$antiporters catalyze proton accumulation in the cytoplasm while cells are extruding $\mathrm{H}^{+}$during respiration. $\mathrm{Na}^{+}$re-entry in support of $\mathrm{pH}$ homeostasis is achieved by $\mathrm{Na}^{+}$: solute symporters. When $\mathrm{Na}^{+}$entry is limited, e.g., at low [ $\mathrm{Na}^{+}$] concentrations or a lack of symporter substrates, the voltage-gated $\mathrm{Na}$ channel operates as a physiologically important ensuring a re-entry route for $\mathrm{Na}^{+}$. The $\mathrm{Na}^{+}$-driven flagellar motor (MotPS channel) functions as a secondary pathway. SDH, succinate dehydrogenase; $\mathrm{MQ}$, menaquinone; Ndh-Il, type II NADH:quinone oxidoreductase.

Descriptions of a unique "alkaliphily" motif in the $c$-ring of ATP synthase from alkaliphilic B. pseudofirmus OF4 had been noted in earlier studies of alkaliphilic bacteria (Liu et al., 2009; Fujisawa et al., 2010). This alkaliphile OXPHOS motif could underpin the efflux of protons by the respiratory chain. Nonetheless, the amount of protons is not in equilibrium with that of the external environment. Consequently, during ATP synthesis, protons are directly transferred to $\mathrm{F}_{1} \mathrm{~F}_{\mathrm{o}}$-ATP synthase through the cytoplasmic membrane. Results of differential scanning calorimetry analysis and saturation transfer electron spin resonance provided indirect evidence for the interaction between the $\mathrm{caa}_{3}$-type terminal oxidase and $\mathrm{F}_{1} \mathrm{~F}_{\mathrm{o}}$-ATP synthase in the proteoliposome (Liu et al., 2007). However, no reports demonstrate the presence of a direct interaction between $\mathrm{Caa}_{3}$ type oxidase and $\mathrm{F}_{1} \mathrm{~F}_{\mathrm{o}}$-ATP synthase.

The hypothetical small protein BH2819 containing 62 amino acids was identified as a complementation gene product of an alkaline $\mathrm{pH}$-sensitive mutant, which was isolated from alkaliphilic $B$. halodurans $\mathrm{C}-125$ by chemical mutagenesis using ethyl methanesulfonate (Aono et al., 1993). Since the BH2819 mutants showed both decreased NADH oxidase activity and loss of growth at a highly alkaline $\mathrm{pH}$, the potential involvement of the BH2819 protein in alkali mechanisms attracted scientific interest, particularly regarding the respiratory chain complexes. The previous evidence of a lack of genetic accessibility of the target gene disruption technique of $B$. halodurans $\mathrm{C}-125$ genomic DNA, whole genome sequencing of $B$. pseudofirmus OF4, a closely related species to $B$. halodurans $\mathrm{C}-125$, was performed.
The result revealed a homologous protein of $\mathrm{BH} 2819$, designated BpOF4_01690, a monocistronic small protein, which was unique and found mostly in alkaliphilic Bacillus species (Figure 2) (Janto et al., 2011). BpOF4_01690 is a low-molecular-weight protein that, similarly to the $\mathrm{BH} 2819$ protein, consists of only 59 amino acids (GenBank accession no. ADC48406.1).

In major studies on small proteins reported by Hobbs et al. (2011) and Storz et al. (2014), this type of protein was defined as proteins made up of $<50$ amino acids (aa’s). However, we encountered a somewhat larger protein in alkaliphilic B. pseudofirmus OF4: BpOF4_01690 with 59 aa's and a similar protein from $B$. halodurans $\mathrm{C}-125, \mathrm{BH} 2819$ with 62 aa's. While not quite as small as the "small proteins" studied by others, they appeared to be sufficiently small to be worthwhile examining in this context.

Many small proteins studied to date are classified as integral membrane proteins. The function of small proteins is diverse, including spore formation, cell division, transport, and the activities of membrane-bound enzymes, such as we were studying, as well as protein kinases, and signal transduction systems (Su et al., 2013; Storz et al., 2014). It has been reported that the small protein Rcf1 plays an important role in the formation of respiratory chain supercomplexes of mitochondria (Chen et al., 2012). Rcf1 is interposed between complex III and IV, and its function is to promote the formation of the supercomplex. Consequently, respiratory failure occurs in the mitochondrial respiratory chains of Rcf1-defective mutants. 


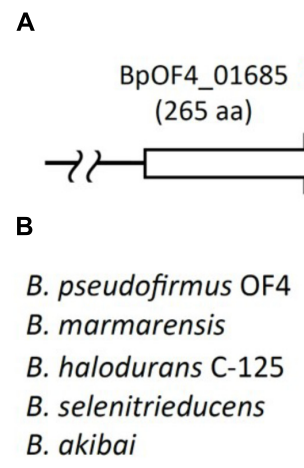

A
C

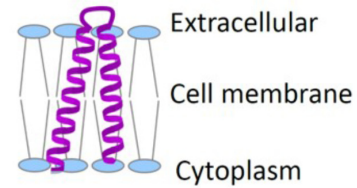

Positive Negative

(211 aa)

(59 aa)

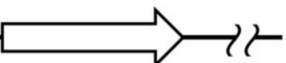

1 MFLAITFLLVAILSAVGIVREMRRKNEFAVGFAALSLAVFGWESVMTIISIIAGGGATA--- 59

1 MFLAITFLLVAILSAVGIVREMRRKNFFAVGFAALSLAVFGWESVMTIISIIAGGGATA--- 59

1 MFVAVTMLLVAILCGLAVVRELRRKNLFAVGFAAISMAVFGWESIATIVTYISSGGTQGIPM 62

1 MFLGILTLLVAILSLIGGYRELKKKNFFAVGFAALSVALFGWESIRTLISIIFTGGGGTV-- 60

1 MILSIILLIVALLSAVAIVREIKRKNFFAVGFAGISFVVFGWESIATIISIITTGTGAPVAH 62

Transmembrane Loop Transmembrane

FIGURE 2 | Features of BpOF4_01690. (A) The arrangement of BpOF4_01690 and the surrounding genes. (B) Multiple alignment analysis of BpOF4_01690 and its homologous proteins was performed using Uniprot (http://www.uniprot.org/). The positively charged amino acid residues are denoted in green, whereas the negatively charged amino acid residues are shown in pink. Transmembrane region prediction was performed using SOSUI (http://harrier.nagahama-i-bio.ac.jp/sosui/) and TMHMM server ver. 2 (http://www.cbs.dtu.dk/services/TMHMM/). (C) Estimated schematic diagram of BpOF4 01690 from the secondary protein structure prediction and hydropathy profile.

In the present study, we used B. pseudofirmus OF4, which was successfully subjected to genome engineering. First, a BpOF4_01690-deleted strain (named $\Delta 01690$ ) was constructed from $B$. pseudofirmus OF4. Then, growth experiments at neutral and alkaline $\mathrm{pH}$ and several $\mathrm{Na}^{+}$concentrations were conducted. In addition, media with different carbon sources were examined in the wild type B. pseudofirmus OF4-811M and in the $\Delta 01690$ mutant. The activities of the respiratory chain complexes of the wild type and $\Delta 01690$ mutant were also compared. This investigation is aimed at identifying the physiological role of small protein BpOF4_01690 at highly alkaline pH.

\section{MATERIALS AND METHODS}

\section{Bacterial Strains and Plasmids}

The bacterial strains and plasmids used in the present study are listed in Table 1, and the primers utilized in our investigation are available on request. The wild type strain was alkaliphilic B. pseudofirmus OF4 (Clejan et al., 1989), whose whole genome had been previously sequenced (Janto et al., 2011). The BpOF4_01690 gene and ctaD (accession no. BpOF4_00910) deletion mutant were individually constructed in the native alkaliphile host as described previously (Liu et al., 2013). Briefly, to construct the $\Delta 01690$ strain, upstream and downstream flanking regions of the BpOF4_01690 gene of approximately 800 bp were amplified using B. pseudofirmus OF4 genomic DNA as the template and subsequently cloned into pGEM7Zf $\left(+\right.$ ) (Promega) and $\mathrm{pG}^{+}$host4 (Appligene, Pleasanton, $\mathrm{CA}$, United States) sequentially. The resulting $\mathrm{pG}^{+}$host4 construct was transformed into the B. pseudofirmus OF4 strain by protoplast transformation (Ito et al., 1997). The $\Delta 01690$ strain was constructed after a single crossover step and a double crossover recombination step. The deletion region was verified by DNA sequencing performed by Eurofins Genomics K.K. (Tokyo, Japan). Restoration of a functional BpOF4_01690 gene in the mutant strain $\Delta 01690$ was achieved by applying a similar strategy to replace the region that was disrupted in the mutants with the sequence of the wild type. The $\triangle c t a D$ strain was constructed in a similar way. The deleted atpBEF (a, c, and b subunit of the $\mathrm{F}_{\mathrm{o}}$ part of ATPase, accession no. BpOF4_06880, BpOF4_06875, and BpOF4_06870) of B. pseudofirmus OF4 was used for the development of the $\Delta \mathrm{F}_{\mathrm{o}}$ strain (Wang et al., 2004). The $\beta$-His strain of $B$. pseudofirmus OF4 containing a six-codon addition encoding 6-His just after the $\mathrm{N}$-terminal methionine of the $\beta$-subunit of $F_{1}$ part of ATPase (AtpD, accession no. BpOF4_06850) was used for immune blotting and pull-down assay (Fujisawa et al., 2010).

\section{Growth Media and Conditions}

Two types of media were used for the experiments; they were buffered at $\mathrm{pH} 7.5$ and 10.5. Either malate (to $50 \mathrm{mM}$ ) was used as the carbon source to support non-fermentative growth or glucose (to $50 \mathrm{mM}$ ) to promote fermentative growth. The semi-defined media with the above-mentioned respective carbon sources were referred to as KMYE (potassium malate-yeast extract) and KGYE (potassium glucose-yeast extract) media (Wang et al., 2004). The KMYE medium ( $\mathrm{pH}$ 10.5) contained $6.70 \mathrm{~g}$ of malic acid, $1 \mathrm{~g}$ of Yeast Extract, $12.44 \mathrm{~g}$ of $\mathrm{K}_{2} \mathrm{CO}_{3}, 1 \mathrm{~g}$ of $\mathrm{KHCO}_{3}, 0.136 \mathrm{~g}$ of $\mathrm{K}_{2} \mathrm{HPO}_{4}, 0.025 \mathrm{~g}$ of $\mathrm{MgSO}_{4} \cdot 7 \mathrm{H}_{2} \mathrm{O}$, and $1 \%(\mathrm{v} / \mathrm{v})$ trace elements per liter of deionized water. The $\mathrm{pH}$ was adjusted to 10.5 with potassium hydroxide solution. The KMYE medium ( $\mathrm{pH} 7.5$ ) contained $6.70 \mathrm{~g}$ of malic acid, $1 \mathrm{~g}$ of Yeast Extract, $16.37 \mathrm{~g}$ of $\mathrm{K}_{2} \mathrm{HPO}_{4}, 0.8 \mathrm{~g}$ of $\mathrm{KH}_{2} \mathrm{PO}_{4}, 0.025 \mathrm{~g}$ of $\mathrm{MgSO}_{4} \cdot 7 \mathrm{H}_{2} \mathrm{O}$, and $1 \%(\mathrm{v} / \mathrm{v})$ trace elements per liter of deionized water. The $\mathrm{pH}$ was adjusted to 7.5 with potassium hydroxide solution. KGYE medium contained the same composition as that of the KMYE medium except for the carbon source which was $9 \mathrm{~g}$ of glucose. MYE medium ( $\mathrm{pH} 10.5$ ) was used for growth of the $\beta$-His strain. The MYE medium contained $6.70 \mathrm{~g}$ of malic acid, $1 \mathrm{~g}$ of yeast extract, $9.54 \mathrm{~g}$ of $\mathrm{Na}_{2} \mathrm{CO}_{3}, 0.84 \mathrm{~g}$ of $\mathrm{NaHCO}_{3}, 0.136 \mathrm{~g}$ of $\mathrm{K}_{2} \mathrm{HPO}_{4}$, $0.025 \mathrm{~g}$ of $\mathrm{MgSO}_{4} \cdot 7 \mathrm{H}_{2} \mathrm{O}$, and $1 \%(\mathrm{v} / \mathrm{v})$ trace elements per liter 
TABLE 1 | Bacterial strains and plasmids used in this study.

\begin{tabular}{|c|c|c|}
\hline Strain and plasmid & Genotype and description & Source and reference \\
\hline \multicolumn{3}{|l|}{ E. coli strains } \\
\hline $\mathrm{DH} 5 \alpha \mathrm{MCR}$ & $\begin{array}{l}\text { F-mcrA } \Delta 1 \text { (mrr-hsd RMS-mcrBC) } \Phi 80 \text { dlacZ } \Delta \text { (lacZYAargF) U169 deoR } \\
\text { recA1 endA1 supE44 } \lambda \text { thi-1 gyr-496 relA1 }\end{array}$ & Stratagene \\
\hline XL1-Blue MRF' & $\begin{array}{l}\Delta(\text { mcrA }) 183 \Delta \text { (mcrCB-hsdSMR-mrr)173 endA1 supE44 thi-1 recA1 } \\
\text { gyrA96 relA1 lac [F'proAB laclaZDM15 Tn10 (Tetr)] }\end{array}$ & GIBCO/BRL \\
\hline \multicolumn{3}{|c|}{ Bacillus pseudofirmus OF4 strains } \\
\hline $811 \mathrm{M}$ & Wild type, Met $^{-}$ & Clejan et al., 1989 \\
\hline$\Delta 01690$ & 811M, sBpOF4_01690 & This study \\
\hline$\Delta 01690-\mathrm{R}$ & $\Delta 01690$, BpOF4_01690 restored at the native location & This study \\
\hline$\Delta 01690-\mathrm{R}-\mathrm{His}_{6}$ & $\begin{array}{l}\Delta 01690, \text { BpOF4_01690 with } 6 x \text { His-tag at C-terminal side restored at } \\
\text { the native location }\end{array}$ & This study \\
\hline$\Delta c t a D$ & $811 \mathrm{M}, \Delta \operatorname{ctaD}$ & This study \\
\hline$\Delta \mathrm{F}_{\mathrm{O}}$ & $811 \mathrm{M}, \triangle a t p B E F$ & Wang et al., 2004 \\
\hline$\beta$-His & $811 \mathrm{M}$, AtpD with $6 \mathrm{xHis}$-tag at $\mathrm{N}$-terminal side & Fujisawa et al., 2010 \\
\hline \multicolumn{3}{|l|}{ Plasmids } \\
\hline pGEM7Zf(+) & Cloning vector $\mathrm{Amp}^{R}$ & Promega \\
\hline pGEM7zf(+)__01690 & pGEM7zf(+) plus BpOF4__01690 fragment & This study \\
\hline pMW118 & Cloning vector $\mathrm{Amp}^{R}$ & Nippon Gene \\
\hline pMW118_01690-R & pMW118+BpOF4_01690 fragment & This study \\
\hline $\mathrm{pG}^{+}$host4 & Temperature-sensitive vector, Erm ${ }^{R}$ & Appligene \\
\hline 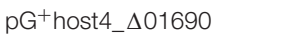 & $\mathrm{pG}^{+}$host4 + BpOF4_. 01690 fragment & This study \\
\hline pG+host4_01690-R & pG ${ }^{+}$host4 + BpOF4_01690 fragment & This study \\
\hline pG+host4_01690-R-His 6 & pG+host4 + BpOF4_01690 with 6xHis-tag at C-terminal side fragment & This study \\
\hline $\mathrm{pG}^{+}$host4_sctaD & $\mathrm{pG}^{+}$host $4+\Delta c t a D$ fragment & This study \\
\hline
\end{tabular}

of deionized water ( $\mathrm{pH}$ 10.5). The $\mathrm{pH}$ was adjusted to 10.5 with sodium hydroxide solution. An E. coli strain was grown at $30^{\circ} \mathrm{C}$ for derivatives of $\mathrm{pG}^{+}$host 4 or $37^{\circ} \mathrm{C}$ for another plasmid in $\mathrm{LB}$ medium. When antibiotics are required for growth selection, the particular medium was supplemented with erythromycin (0.3-0.6 $\mu \mathrm{g} / \mathrm{ml}$ for B. pseudofirmus and $150-300 \mu \mathrm{g} / \mathrm{ml}$ for E. coli) or ampicillin $(100 \mu \mathrm{g} / \mathrm{ml})$. The cells were grown at $37^{\circ} \mathrm{C}$ with shaking. Their growth was monitored by measuring the absorbance at $600 \mathrm{~nm}$ using a spectrophotometer.

\section{Alignment of the Small Protein With Homologous Proteins of Several Bacterial Species}

The amino acid sequences of BpOF4_01690 and several homologs were obtained using the BLASTP algorithm at $\mathrm{NCBI}^{1}$. Selected amino acid residues in the alignment were analyzed using ClustalW2.

\section{Isolation of Everted Membrane Vesicles and ATPase Assays}

Everted membrane vesicles were prepared from overnight cultures grown under several conditions as described previously (Liu et al., 2014). Protein content was determined by the Lowry method using lysozyme as the standard (Lowry et al., 1951).

\footnotetext{
${ }^{1}$ https://blast.ncbi.nlm.nih.gov/Blast.cgi?PROGRAM=blastp\&PAGE_TYPE= BlastSearch\&LINK_LOC=blasthome

${ }^{2}$ https://www.genome.jp/tools-bin/clustalw
}

Octylglucoside-stimulated ATPase assays were performed for $3 \mathrm{~min}$ at $37^{\circ} \mathrm{C}$ and $\mathrm{pH} 8.0$ in a $0.5-\mathrm{ml}$ volume, containing $20 \mathrm{mM}$ Tricine- $\mathrm{NaOH}, 5 \mathrm{mM}$ ATP (sodium salt, Sigma), $2.5 \mathrm{mM} \mathrm{MgCl} 2$, $30 \mathrm{mM}$ octylglucoside, $50 \mathrm{mM} \mathrm{Na} 2 \mathrm{SO}_{3}$, and $20 \mu \mathrm{g}$ membrane protein (Liu et al., 2014). Subsequently, a $0.5-\mathrm{ml}$ volume of $\mathrm{Pi}$ detection solution containing $0.3 \mathrm{ml}$ of LeBel reagent was added, which comprised $1 \%$ sodium sulfate, $0.4 \%$ 4-(methylamino) phenol, and $1 \%$ ammonium molybdate. The reactions were incubated for $5 \mathrm{~min}$ at room temperature and terminated by a $0.1-\mathrm{ml}$ volume of $34 \%$ sodium citrate. The precipitated protein was removed by centrifugation, and the liberated $\mathrm{P}_{\mathrm{i}}$ in the supernatants was measured at $750 \mathrm{~nm}$ according to Lebel et al. (1978).

\section{Assays of Respiratory Chain Components}

All enzyme assays were performed at room temperature using a Shimadzu UV-1800 UV-Visible spectrophotometer. Tris-HCl (50 mM, pH 8) was utilized as the assay buffer, and $1 \mathrm{ml}$ of 50 or $100 \mu \mathrm{g}$ of everted membrane vesicle protein was used as the assay volume. NADH oxidase assays were performed by monitoring the decrease of $A_{340}$ over time in the presence of $0.2 \mathrm{mM} \mathrm{NADH}$. The NADH-ferricyanide oxidoreductase activity was measured at $420 \mathrm{~nm}$ in a buffer containing $1 \mathrm{mM}$ $\mathrm{NADH}, 1 \mathrm{mM} \mathrm{K} \mathrm{K}_{3} \mathrm{Fe}(\mathrm{CN})_{6}$, and $10 \mathrm{mM} \mathrm{KCN}$, as described previously (Swartz et al., 2007). Succinate dehydrogenase activity was monitored by following the phenazine methosulfate-coupled reduction of 2,6-dichloroindophenol at $600 \mathrm{~nm}$ (Hatefi, 1978). The reaction mixture, consisting of $10 \mathrm{mM}$ succinate, $50 \mu \mathrm{g}$ 
vesicles, and $10 \mathrm{mM} \mathrm{KCN}$, was preincubated for $5 \mathrm{~min}$ at room temperature. Then, $0.07 \mathrm{mM}$ 2,6-dichloroindophenol and $1.625 \mathrm{mM}$ phenazine methosulfate were added to initiate the reaction. The $N, N, N$ ', $N$ '-tetramethyl- $p$-phenylenediamine (TMPD) oxidase level was determined by monitoring the increase in $A_{562}$ in the presence of $0.25 \mathrm{mM}$ TMPD (Sakamoto et al., 1996). The extinction coefficients $\left(\mathrm{mM}^{-1} \mathrm{~cm}^{-1}\right)$ used for activity calculations were as follows: 6.2 at $340 \mathrm{~nm}, 1$ at $420 \mathrm{~nm}, 21$ at $600 \mathrm{~nm}$, and 10.5 at $562 \mathrm{~nm}$. One unit (U) was defined as $1 \mu \mathrm{mol}$ of substrate reduced or oxidized per minute per mg of protein.

\section{Immunoblot Analysis of BpOF4_01690-6xHis Protein in Strain $\Delta$ 01690-R-His 6 Membrane Fractions}

Five microliters of membrane suspension (4 $\mu \mathrm{g}$ of membrane protein/ $\mu \mathrm{l}$ ) from each sample was used for one-dimensional sodium dodecyl sulfate (SDS)-PAGE analyses of the membrane samples. The same volume of SDS loading buffer was added to each sample, after which the proteins were separated on $12 \%$ polyacrylamide SDS gels. Next, the gels were electrophoretically transferred to nitrocellulose filters (Bio-Rad) by the application of $60 \mathrm{~V}$ for $3 \mathrm{~h}$ in Tris-glycine-methanol buffer [25 mM Tris, $192 \mathrm{mM}$ glycine, and $20 \%(\mathrm{v} / \mathrm{v})$ methanol ( $\mathrm{pH} 8.3)]$. The BpOF4_01690-His6 protein was detected by anti-His antibody HRP conjugate (Qiagen). ECL solution (Promega) was the usual detection reagent. A quantitative imaging system, PluorS MAX (Bio-Rad), was used for the detection and analysis of chemiluminescence images.

\section{Heme Staining Analysis of Cytochrome Content}

For heme staining and subsequent analyses, $30 \mu \mathrm{g}$ of everted membrane vesicle protein was separated by native 12\% PAGE (Schagger and Von Jagow, 1987). The gels were immersed for $30 \mathrm{~min}$ at room temperature in the dark in $25 \mathrm{ml}$ of staining solution ( $\mathrm{pH} 4.7$ ) containing $0.5 \mathrm{mg} / \mathrm{ml} \mathrm{3,3}, 5,5^{\prime}$ tetramethylbenzidine, 50\% methanol, and $1 \mathrm{M}$ sodium acetate (Guikema and Sherman, 1981), with slow shaking, after which $\mathrm{H}_{2} \mathrm{O}_{2}$ was added to $0.5 \%$. The stained bands appeared in $5 \mathrm{~min}$, after which the gels were scanned. The bands were quantified by Image 1.47 software and described as $\%$ of WT, with WT set at $100 \%$.

\section{Solubilization of Membrane Proteins From the $\beta$-His Strain}

Membrane vesicles were prepared from overnight cultures grown in MYE medium at $\mathrm{pH} 10.5$ as described previously (Liu et al., 2009). $10 \mathrm{mg} / \mathrm{mL}$ membrane proteins from the $\beta$-His strain were solubilized by an extraction solution which contains $200 \mathrm{mM}$ $\mathrm{NaCl}, 1 \%(\mathrm{w} / \mathrm{v})$ dodecyl maltoside (DDM), 3 mM HEPES, $15 \mathrm{mM}$ $\mathrm{MgCl}_{2}$ and $3 \%$ glycerol ( $\mathrm{pH} 8.0$ ). The $\mathrm{pH}$ was adjusted to 8.0 with sodium hydroxide solution. The solution was gently mixed with a nutator at $4^{\circ} \mathrm{C}$ for $1 \mathrm{~h}$. Ultracentrifugation (Beckman Coulter Optima TL 100) was performed at $45,000 \mathrm{rpm}$ at $4^{\circ} \mathrm{C}$ for $1 \mathrm{~h}$ to remove insoluble proteins.

\section{Sucrose Density Gradient Ultracentrifugation}

The Ultra-clear ${ }^{\mathrm{TM}}$ centrifuge tube was first filled with $4 \mathrm{ml}$ of $20 \%$ sucrose and then $4 \mathrm{ml}$ of $30 \%$ sucrose buffer was carefully filled into the bottom of the tube using a needlelong syringe to keep the interface of the buffer as stable as possible. Sucrose buffer contains $2.38 \mathrm{~g}$ of HEPES, $10.17 \mathrm{~g}$ of $\mathrm{MgCl}_{2} \cdot 6 \mathrm{H}_{2} \mathrm{O}, 200 \mathrm{~g}(20 \%)$ or $300 \mathrm{~g}$ (30\%) of sucrose, and $0.15 \%$ DDM per liter of deionized water $(\mathrm{pH} 8.0)$. The $\mathrm{pH}$ was adjusted to 8.0 with sodium hydroxide solution. The tube was capped with parafilm and allowed to stand at room temperature for $2 \mathrm{~h}$ in a tilted state to form a sucrose density gradient. Thereafter, it was left for $1 \mathrm{~h}$ at $4^{\circ} \mathrm{C}$. One milliliter of solubilized membrane protein $(10 \mathrm{mg} / \mathrm{ml})$ solubilized from the $\beta$-His strain was carefully overlaid on the sucrose density gradient. Ultracentrifugation was performed using OptimaTML80XP and an SW40 Ti Rotor (Beckman coulter) at 40,000 rpm at $4^{\circ} \mathrm{C}$ for $16 \mathrm{~h}$. After ultracentrifugation, $400 \mu \mathrm{l}$ of the fraction was carefully separated from the upper layer of the tube, and $A_{280}$ of each fraction was measured with NANO DROP 200c (Thermo Fisher Scientific). Fractions in which cytochrome oxidase activity was observed using TMPD were used for the next analysis.

\section{Immunoblot Analysis of the $\beta$ Subunit of $F_{1}$-ATPase and CtaC Subunit of $\mathrm{caa}_{3}$-Type Terminal Cytochrome Oxidase From Fractions Separated by Sucrose Density Gradient Ultracentrifugation}

A $15 \%$ acrylamide gel was prepared, and a sample buffer was added to each of 23 fractions in which cytochrome oxidase activity was observed and electrophoresed at $30 \mathrm{~mA}$. Blue Star Prestained Protein Marker (NIPPON Genetics) was used as a marker. Proteins in the gel were transferred to nitrocellulose filters (Bio-Rad) by applying electricity at $20 \mathrm{~V}$ for $16 \mathrm{~h}$ in Tris-glycine-methanol buffer [25 mM Tris, $192 \mathrm{mM}$ glycine, and 20\% (v/v) methanol ( $\mathrm{pH}$ 8.3)] using a Mini Trans-Blot ${ }^{\circledR}$ Cell manufactured (Bio-Rad). Western blots were performed as described previously (Morino et al., 2008). The $\beta$ subunit-His 6 protein of ATP synthase was detected by antiHis antibody HRP conjugate (Qiagen). For detection of the CtaC protein, rabbit anti-CtaC polyclonal antibody (Eurofins Genomics) was used as a primary antibody and goat antirabbit IgG-HRP conjugate (Abcam) was used as a secondary antibody. ECL solution (Promega) was the usual detection reagent. A quantitative imaging system, ChemiDoc ${ }^{\mathrm{TM}} \mathrm{XRS}^{+}$ (Bio-Rad) and a PC application software, Quantity One were used for the detection and analysis of chemiluminescence images.

\section{Pull Down Assay and Immunoblot Analysis}

One milliliter of Ni-NTA resin (QIAGEN) was packed in the column. One column volume is $0.5 \mathrm{ml}$. Two to four column volumes of distilled water were passed through the resin and 
TABLE 2 | Result of protein BLAST analysis against BpOF4_01690.

\begin{tabular}{|c|c|c|c|c|}
\hline Strain & Protein names & $\begin{array}{c}\text { GenBank } \\
\text { accession no. }\end{array}$ & Length & $\begin{array}{c}\text { Identity } \\
(\%)\end{array}$ \\
\hline Bacillus pseudofirmus OF4 & BpOF4_01690 & ADC48406.1 & 59 & 100 \\
\hline Bacillus marmarensis DSM 21297 & A33I_13875 & ERN53048.1 & 59 & 100 \\
\hline Bacillus halodurans C-125 & $\mathrm{BH} 2819$ & BAB06538.1 & 62 & 66 \\
\hline Bacillus selenitrieducens ATCC 700615 & Bsel_2302 & ADH99805.1 & 60 & 69 \\
\hline Bacillus akibai JCM 9157 & JCM9157_3465 & GAE36304.1 & 62 & 69 \\
\hline Bacillus hemicellulosilyticus JCM 9152 & JCM9152_3343 & GAE31848.1 & 60 & 63 \\
\hline Bacillus sp. TS-2 & BTS2_0672 & GAF63780.1 & 63 & 67 \\
\hline Bacillus cellulosilyticus DSM 2522 & Bcell_1668 & ADU29931.1 & 60 & 67 \\
\hline Bacillus alcalophilus ATCC 27647 & BALCAV_0219525 & KGA95903.1 & 61 & 62 \\
\hline Bacillus wakoensis JCM 9140 & JCM9140_4660 & GAE28435.1 & 62 & 62 \\
\hline
\end{tabular}

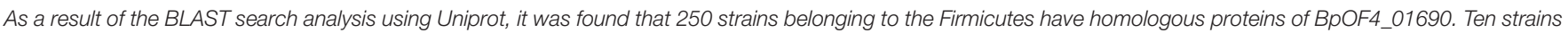
with top 10 scores (values considering similarity and expectation values) were extracted in order. All 10 strains were alkaliphilic Bacillus spp.

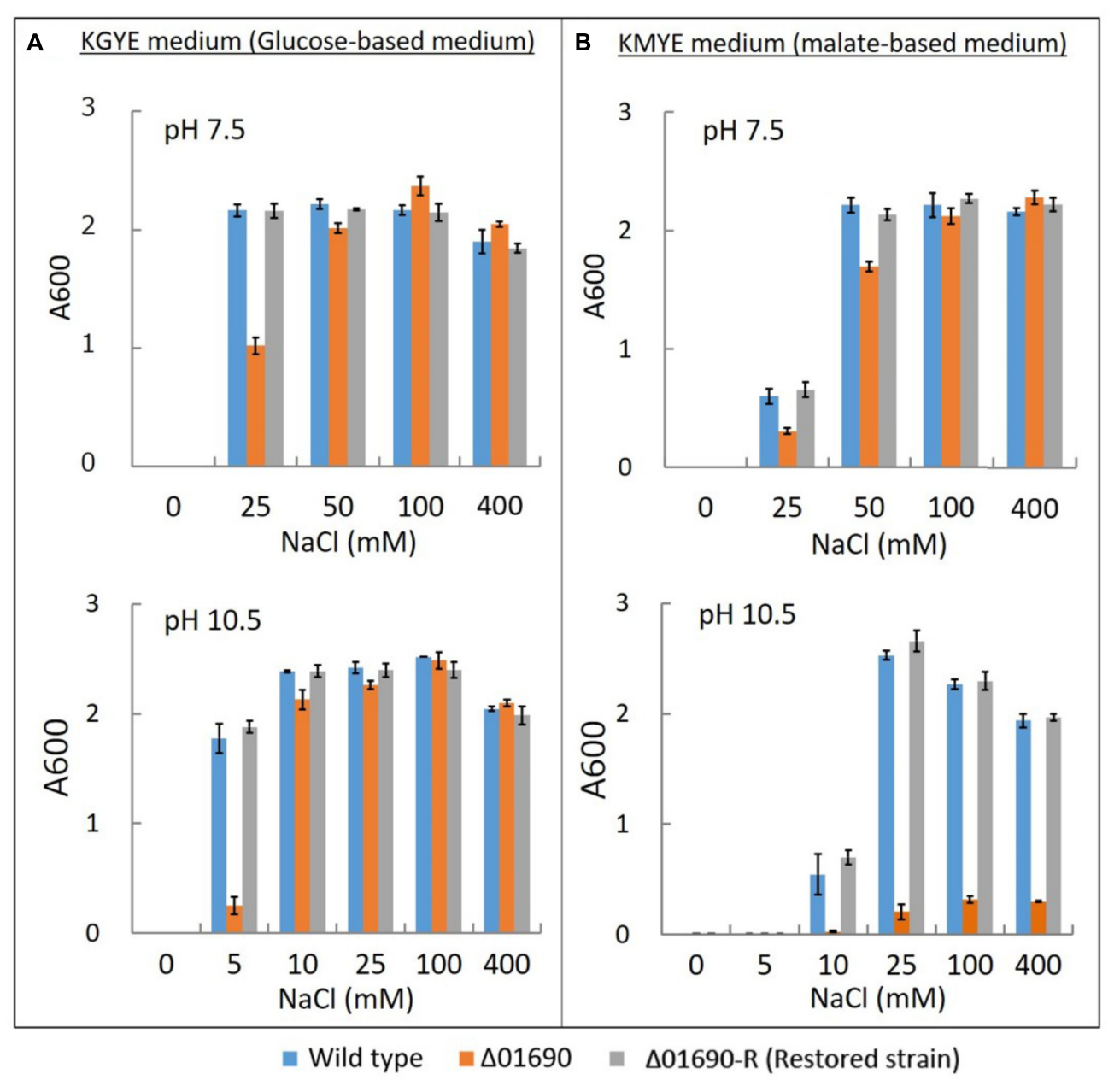

FIGURE 3 | Growth of B. pseudofirmus OF4 (wild type), $\Delta 01690$, and $\Delta 01690-\mathrm{R}$ under various sodium concentrations. As preculture, each cell was grown in a GYE medium ( $\mathrm{pH} 7.5$ ) overnight at $37^{\circ} \mathrm{C}$. Absorbance at $A_{600}$ of each preculture was measured, and the $A_{600}$ of each preculture was adjusted to 1.0. Next, each preculture was harvested by centrifugation and resuspended using the same medium as in the culture so that the glucose and $\mathrm{Na}^{+}$were not transferred from the preculture to the culture. (A,B) Preculture $(2 \mu \mathrm{l})$ was added to $2 \mathrm{ml}$ of KGYE medium (pH 7.5), KGYE medium (pH 10.5), KMYE medium (pH 7.5), and KMYE medium $(\mathrm{pH} 10.5)$ with various concentrations of $\mathrm{NaCl}$ and grown aerobically at $37^{\circ} \mathrm{C}$ for $16 \mathrm{~h}$. The $\mathrm{A}_{600}$ of the cultures was then measured. The error bars indicate standard deviations for the results from duplicate cultures in three independent experiments. 
A

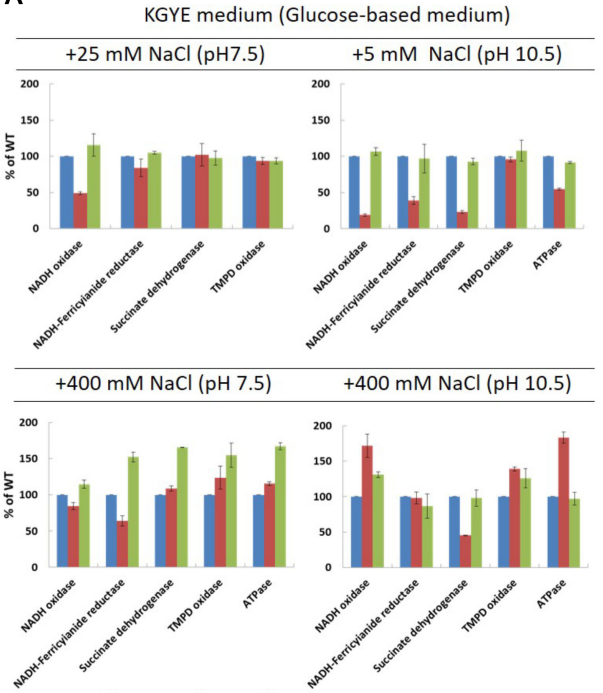

B
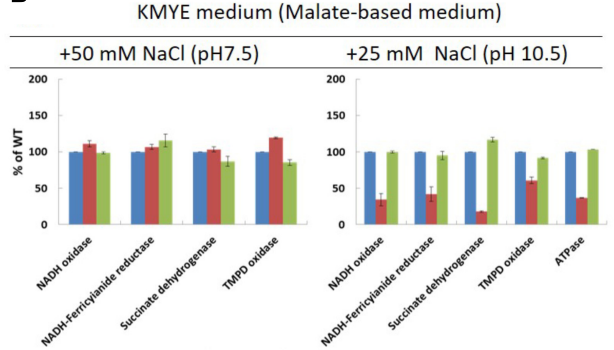

150

150
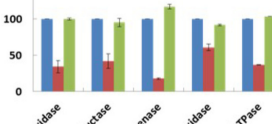

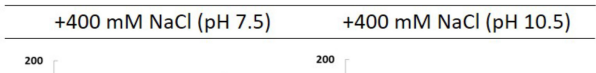

${ }_{150}+150$

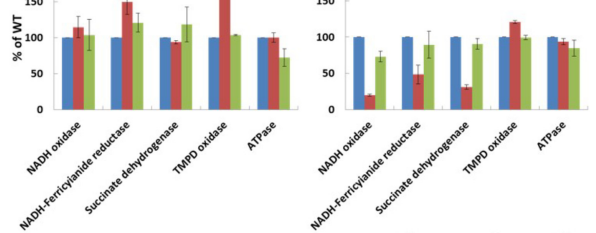

Wild type $\square 01690 \quad \Delta 01690-R$

FIGURE 4 | Measurements of various respiratory chain activates of $B$. pseudofirmus OF4 (wild type), $\Delta 01690$, and $\Delta 01690-R$ under various growth conditions (A: KGYE medium, B: KMYE medium) at pH 7.5 and 10.5. Based on the specific activity of the wild type, referred to as $100 \%$, the specific activities of $\Delta 01690$ and $\Delta 01690-R$ (restored strain) are shown as relative activities (\%). The error bars indicate standard deviations for the results from three independent experiments. The details of the experiment are described in the "Materials and Methods" section.

subsequently 10 column volumes of wash buffer (10 mM HEPES, $5 \mathrm{mM} \mathrm{MgCl}_{2}, 20 \mathrm{mM}$ imidazole, $20 \mathrm{mM} \mathrm{NaCl}$ and $0.15 \%$ DDM, pH 8.0) were applied to the column to wash the resin. Imidazole was added to the membrane protein of the $\beta$-His strain solubilized by DDM to a final concentration of $20 \mathrm{mM}$ and this was applied to the resin. The resin and solubilized membrane protein were well mixed, transferred to a $15 \mathrm{ml}$ tube, and shaken at $4^{\circ} \mathrm{C}$ for $1 \mathrm{~h}$ with a nutator at low speed. Mixed resin and membrane protein were passed through the column to obtain a non-adsorbed fraction. Subsequently, $1 \mathrm{ml}$ of wash buffer was passed through the column to obtain a washed fraction. Finally, $1 \mathrm{ml}$ of elution buffer (10 mM HEPES, $5 \mathrm{mM} \mathrm{MgCl}_{2}, 200 \mathrm{mM}$ imidazole, $20 \mathrm{mM} \mathrm{NaCl}$ and $0.15 \%$ DDM, pH 8.0) was passed through the column, and the eluted fraction was obtained.

The solubilized fraction, non-adsorbed fraction, washed fraction, and eluted fraction obtained by the pull-down assay were used for immunoblotting analysis which was performed in the same manner as described above.

\section{RESULTS AND DISCUSSION}

\section{Verification of the Interaction Between Cytochrome $\mathrm{caa}_{3}$-Type Terminal Oxidase and $F_{1} F_{0}$-ATP Synthase}

Sucrose density gradient ultracentrifugation and pull-down assays were carried out to verify the direct interaction between $\mathrm{F}_{1} \mathrm{~F}_{\mathrm{o}}$-ATP synthase and cytochrome $c a a_{3}$ type terminal oxidase involved in OXPHOS. Indirect interaction between $\mathrm{F}_{1} \mathrm{~F}_{\mathrm{O}}$-ATP synthase and cytochrome $\mathrm{caa}_{3}$ type terminal oxidase of
B. pseudofirmus OF4 has been demonstrated by using saturated mobile electron spin resonance and differential scanning calorimetry analysis (Liu et al., 2007). However, there is no direct report that the two proteins form a complex. Sucrose density gradient centrifugation and pull-down assay were conducted to confirm the interaction of proteins under mild conditions to verify whether these two complexes form a complex in the cell membrane.

From the results of sucrose density gradient ultracentrifugation and its immunoblot analysis, monomeric cytochrome $\mathrm{Caa}_{3}$ type terminal oxidase was detected in low molecular weight fractions, and $\mathrm{F}_{1} \mathrm{~F}_{\mathrm{o}}$-ATP synthase and cytochrome $\mathrm{Caa}_{3}$ type terminal oxidase were simultaneously detected in the high molecular weight fractions (Supplementary Figure S1). This result suggested the possibility of interaction between these two protein complexes. Subsequently, we attempted a pull-down assay to detect direct interactions between them (Supplementary Figure S2). However, the cytochrome $\mathrm{caa}_{3}$-type terminal oxidase was not purified together with the $\mathrm{F}_{1} \mathrm{~F}_{\mathrm{o}}$-ATP synthase. This result suggests that interaction between the two complexes is not strong in the cell membrane, i.e., may be a weak protein interaction. It is also possible that there may be another membrane protein that mediates between the two complexes.

\section{Bioinformatics Analysis of BpOF4_01690}

The results of the BLAST sequence analysis ${ }^{3}$ showed that the homologous small proteins of BpOF4_01690 are present

\footnotetext{
${ }^{3}$ http://blast.ncbi.nlm.nih.gov/Blast.cgi
} 


\section{A}

KGYE medium (Glucose-based medium)
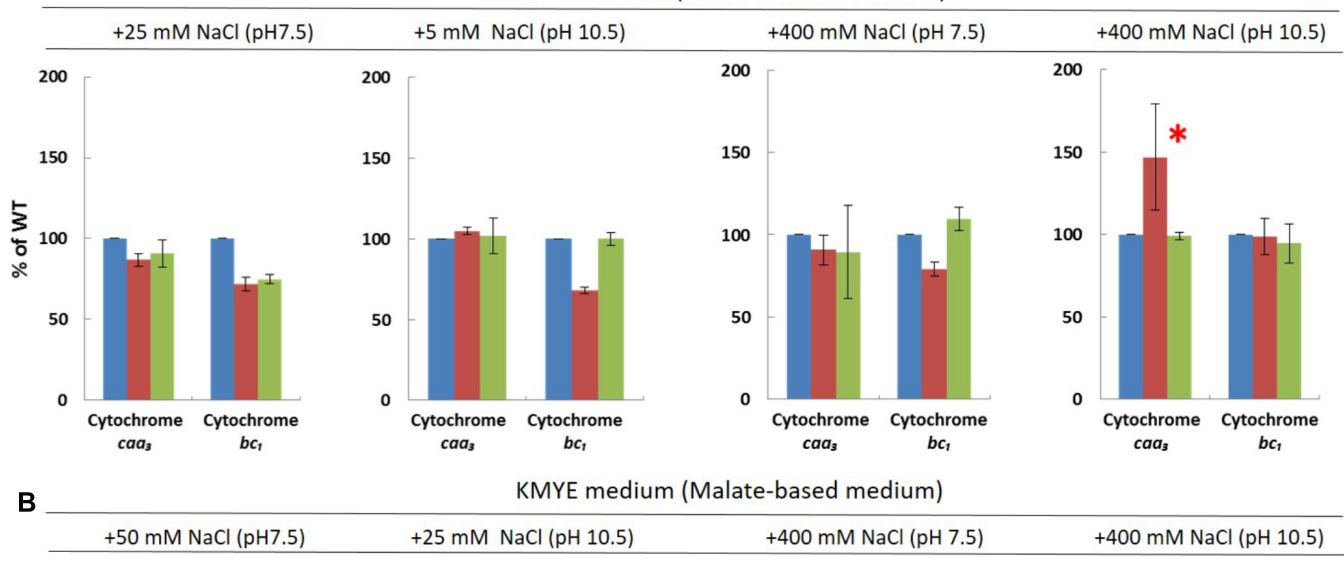

Malate-based medium)
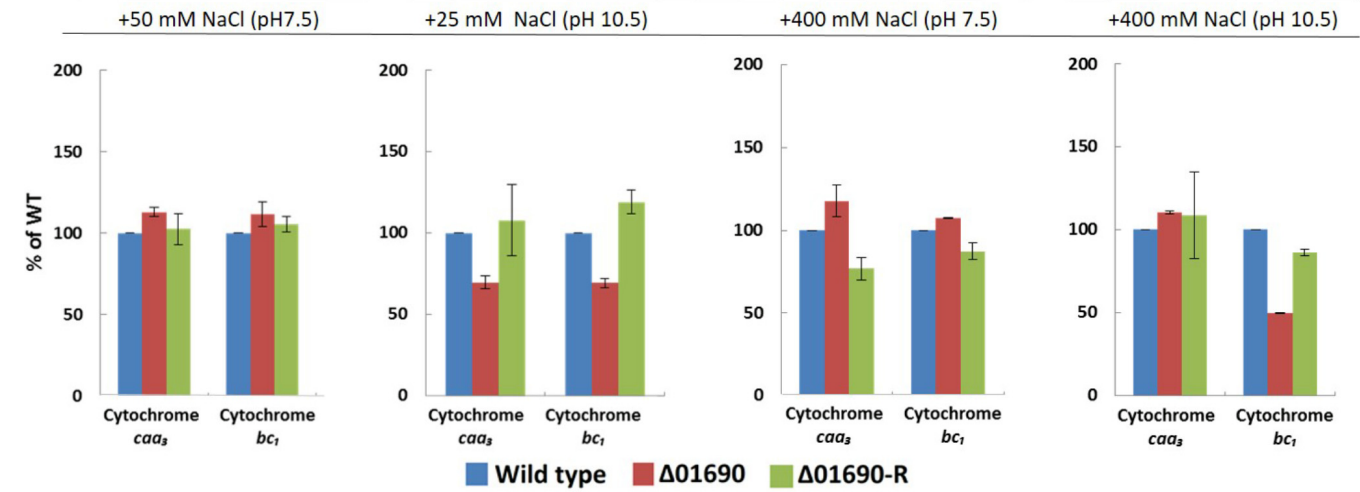

FIGURE 5 | Expression levels of cytochrome caa 3 and cytochrome $b c_{1}$ of $B$. pseudofirmus OF4 (wild type), $\Delta 01690$, and $\Delta 01690-R$ under various growth conditions (A: KGYE medium, B: KMYE medium) at pH 7.5 and 10.5. Based on the expression level of the wild type, referred to as $100 \%$, the expression levels of $\Delta 01690$ and $\Delta 01690-R$ (restored strain) are shown as relative activities (\%). The error bars indicate standard deviations for the results from three independent experiments. The detailed description of the experiment is presented in the "Materials and Methods" section.

predominantly in alkaliphilic Bacillus species (Table 2). The secondary protein structure prediction and hydropathy profile of BpOF4_01690 and its homologs indicated that each protein has two transmembrane-spanning segments and there are highly conserved charged amino acid residues in the loop region between the transmembrane segments (Figures 2B,C). However, no functional motif and domain were identified, and its physiological function remains unknown.

\section{Growth of the Wild Type, $\Delta 01690$, and $\Delta$ 01690-R Under Low-Sodium Conditions}

KGYE (potassium glucose-yeast extract) and KMYE (potassium malate-yeast extract) were used as growth media, in which $\mathrm{K}^{+}$ was used instead of $\mathrm{Na}^{+}$at $\mathrm{pH} 7.5$ and 10.5 (Wang et al., 2004). The major carbon sources in the KGYE and KMYE media were D-glucose and L-malic acid, respectively. In the KGYE medium, glucose was metabolized via the glycolytic pathway, and ATP was synthesized by OXPHOS and substrate-level phosphorylation. In contrast, in the KMYE medium, malic acid was metabolized via the TCA cycle, and ATP was synthesized predominantly by OXPHOS (Supplementary Figure S3).
Alkaliphilic bacteria generally require $\mathrm{Na}^{+}$for growth. Reportedly, $\mathrm{Na}^{+}$in the medium is utilized as a source of coupling ions for flagellar rotation, uptake of various substrates, $\mathrm{Na}^{+} / \mathrm{H}^{+}$ antiporters, voltage-gated sodium channel, etc. (Krulwich and Ito, 2013; Preiss et al., 2015; Ito et al., 2017; Morino et al., 2017). Therefore, ensuring optimal $\mathrm{Na}^{+}$concentration is critical for the provision of favorable growth conditions. Earlier reports showed that higher $\mathrm{NaCl}$ concentrations were required at $\mathrm{pH} 7.5$ than at pH 10.5 to support optimal growth rates (Ito et al., 1997). Thus, to determine the effect of $\mathrm{Na}^{+}, \mathrm{K}^{+}$was used as a substitute for $\mathrm{Na}^{+}$ in the KGYE and KMYE media. Then, growth experiments with various concentrations of added $\mathrm{Na}^{+}$were conducted (Figure 3) (Terahara et al., 2012).

The growth of the wild type, $\Delta 01690$, and $\Delta 01690-\mathrm{R}$ in the KGYE medium at $\mathrm{pH} 7.5$ was almost identical to the growth with the addition of $50 \mathrm{mM} \mathrm{Na}{ }^{+}$. However, $50 \%$ of the growth of $\Delta 01690$ was observed at $25 \mathrm{mM} \mathrm{Na}^{+}$compared with wild type and $\Delta 01690-\mathrm{R}$ (Figure 3A). Moderate decline in growth of $\triangle 01690$ in the KMYE medium at $\mathrm{pH} 7.5$ was observed under $25 \mathrm{mM}$ and $50 \mathrm{mM} \mathrm{Na}^{+}$conditions compared to wild type and $\Delta 01690-\mathrm{R}$ (Figure 3B). In contrast, the growth of the wild type, $\Delta 01690$, and $\Delta 01690-\mathrm{R}$ in the KGYE medium at $\mathrm{pH} 10.5$ was almost identical to that in the medium with the addition of 


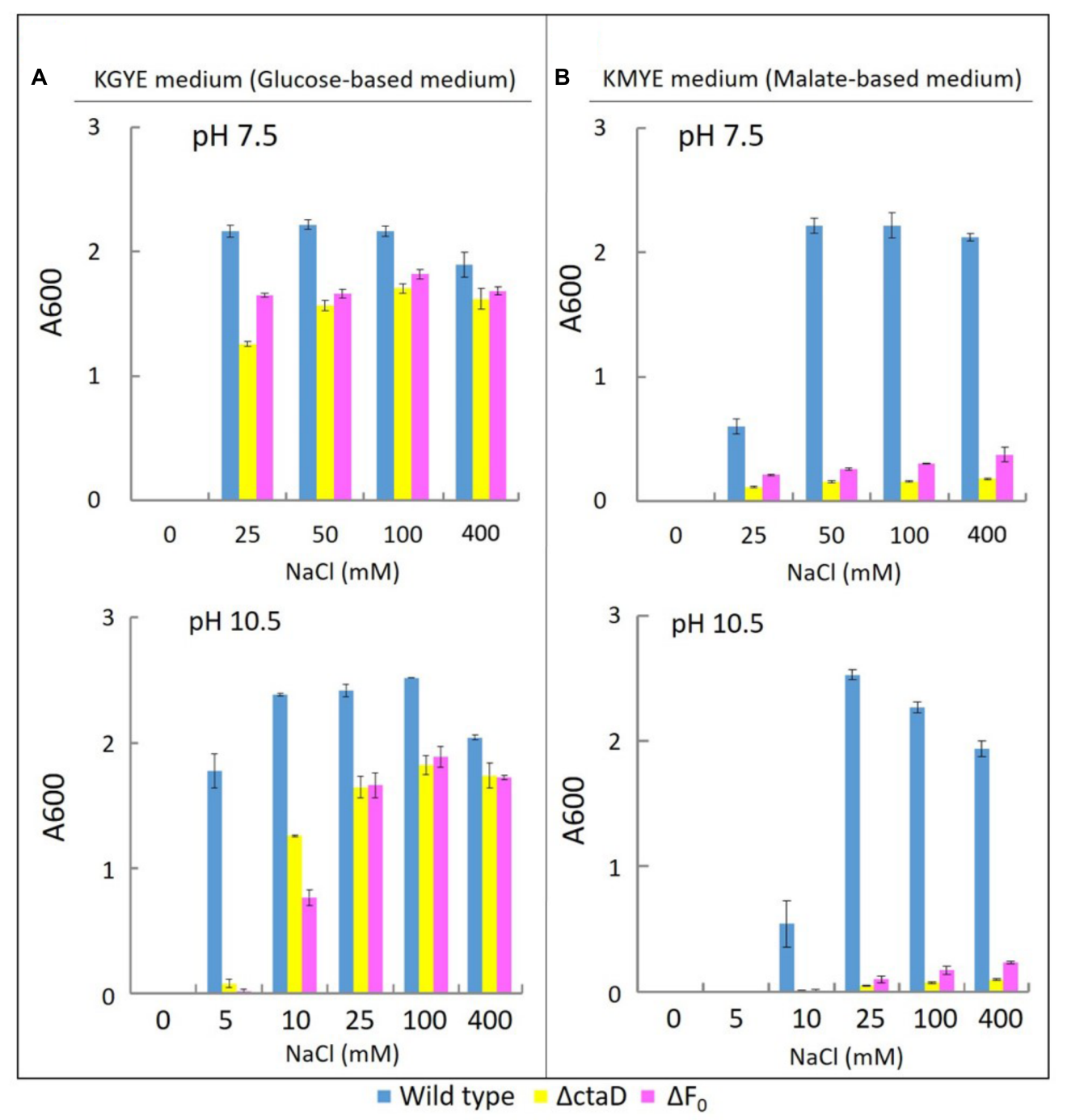

FIGURE 6 | Growth of B. pseudofirmus OF4 (wild type), $\Delta c t a D$, and $\Delta \mathrm{F}_{\mathrm{o}}$ under various $\mathrm{Na}^{+}$concentrations (A: KGYE medium, B: KMYE medium). The experimental method used is the same as that outlined in the legend of Figure 3.

$10 \mathrm{mM} \mathrm{Na}^{+}$. Nevertheless, at $5 \mathrm{mM} \mathrm{Na}^{+}$, the growth of $\Delta 01690$ was poorer than that in the wild type and $\Delta 01690-\mathrm{R}$ (Figure 3A). Poor growth of $\Delta 01690$ was observed under all tested conditions in the KMYE medium at $\mathrm{pH} 10.5$. Both the wild type and $\Delta 01690$ grew well in $\mathrm{NaCl}$ concentrations over 25-400 mM (Figure 3B).

\section{Comparison of the Expression Level of Protein BpOF4_01690 Under Different Growth Conditions}

The expression level of BpOF4_01690 fused with 6xHis-tag in the strain $\Delta 01690-\mathrm{R}-\mathrm{His}_{6}$ cultured in KMYE and KGYE media at $\mathrm{pH} 10.5$ was detected by western blotting (Supplementary Figure S4). The highest expression level was detected when the cells were grown on KMYE medium containing $25 \mathrm{mM} \mathrm{Na}^{+}$ at $\mathrm{pH}$ 10.5. However, no dramatic increase or decrease in the protein expression was detected under either condition.

\section{Measurements of Diverse Respiratory Chain Activities and Expression Levels of Cytochrome $b c_{1}$ of the Wild Type, $\Delta 01690$, and $\Delta 01690-R$}

Under the condition that the growth of $\Delta 01690$ is worse than that of the wild type, enzymatic activities of various respiratory chain complexes of the wild type were measured in both $\Delta 01690$ and $\Delta 01690-\mathrm{R}$ under high- and low-sodium conditions at $\mathrm{pH}$ 7.5 and 10.5 (Figure 4). The activities of NADH oxidase, NADH ferricyanide reductase, succinate dehydrogenase, TMPD oxidase, and $\mathrm{F}_{1} \mathrm{~F}_{\mathrm{o}}$-ATPase were lower than those in the wild type in the KMYE medium plus $25 \mathrm{mM} \mathrm{NaCl}$ at $\mathrm{pH} 10.5$ (Figure 4B, upper right). The high $\mathrm{NaCl}$ concentration (400 mM) in the KMYE medium at $\mathrm{pH} 10.5$ enabled recovery of the activity of TMPD oxidase and ATPase (Figure 4B, bottom right). Both KGYE medium plus $5 \mathrm{mM} \mathrm{NaCl}$ at $\mathrm{pH} 10.5$ 


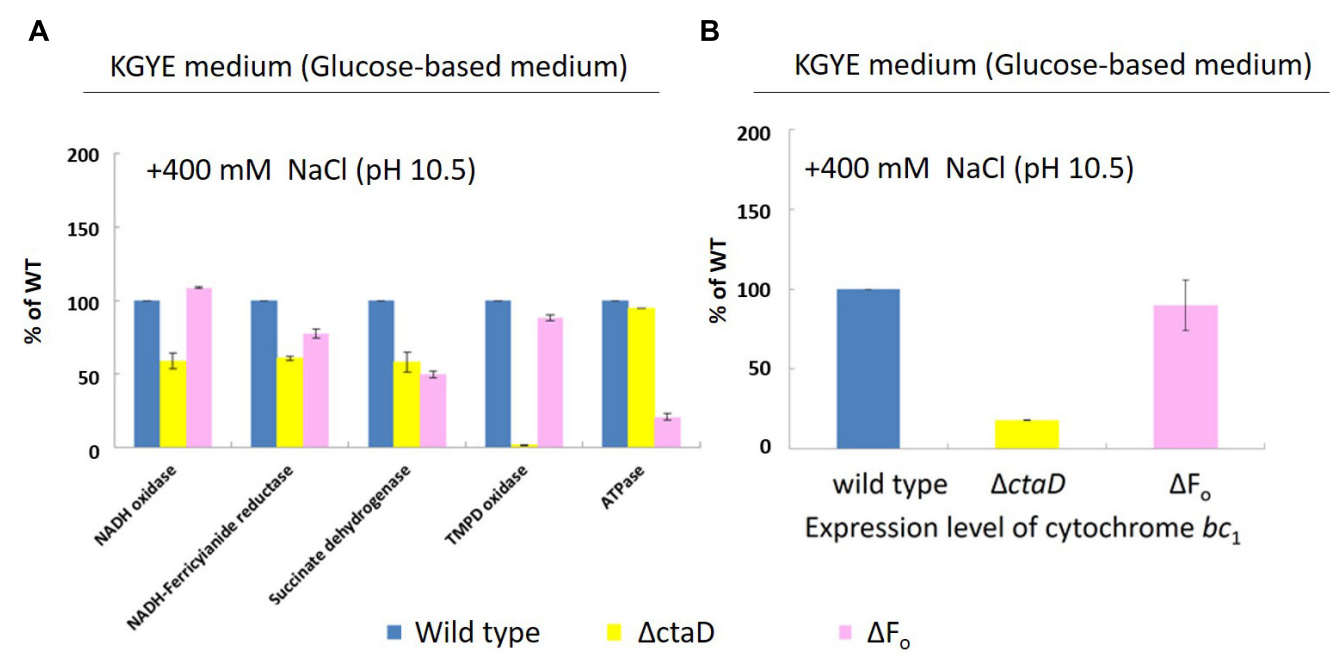

FIGURE 7 | Measurements of various respiratory chain activities (A) and the expression level of cytochrome bc1 (B) of B. pseudofirmus OF4 (wild type), $\Delta$ ctaD, and $\Delta F_{0}$ in the KGYE medium plus $400 \mathrm{mM} \mathrm{Na}^{+}$at $\mathrm{pH} 10.5$. Based on the specific activity of the wild type, referred to as $100 \%$, the specific activities of $\Delta c t a D$ and $\Delta \mathrm{F}_{0}$ are displayed as relative activities (\%). The error bars indicate standard deviations for the results from three independent experiments. The details of the experiment are described in the "Materials and Methods" section.

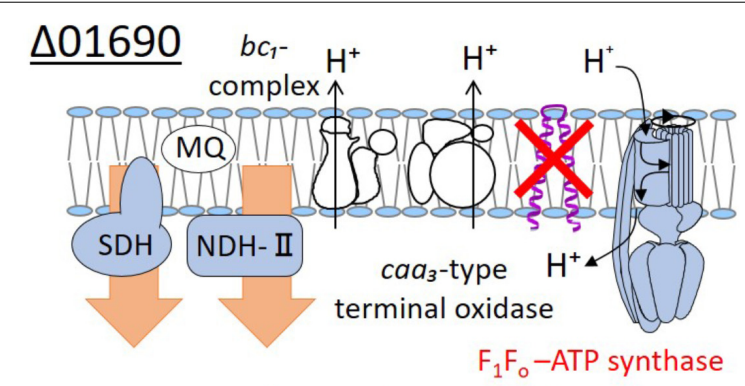

KGYE medium + $5 \mathrm{mM} \mathrm{NaCl}(\mathrm{pH} 10.5)$
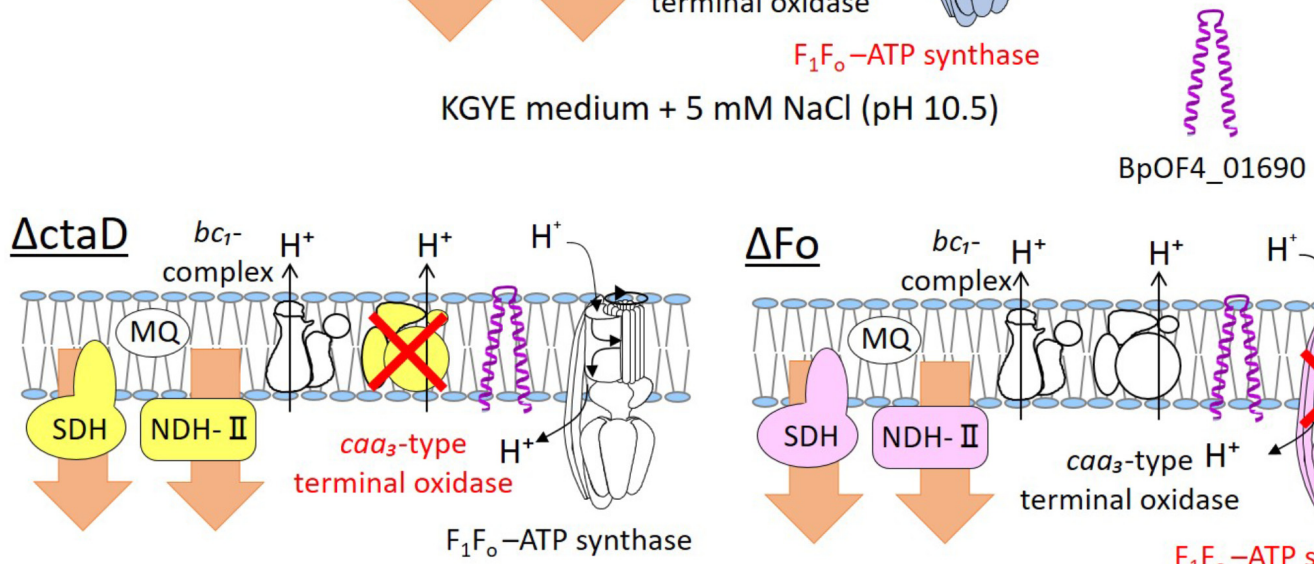

KGYE medium + $10 \mathrm{mM} \mathrm{NaCl}(\mathrm{pH} 10.5)$

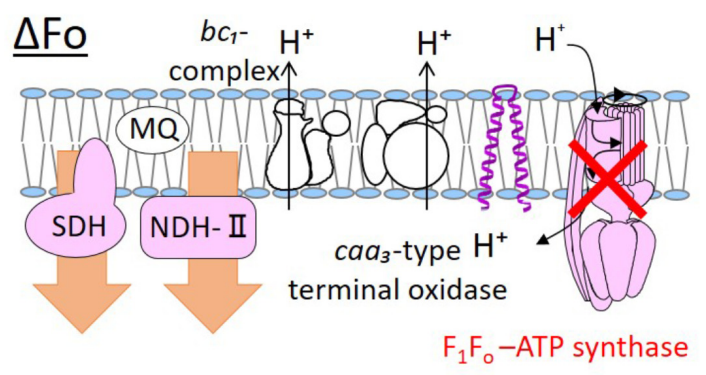

KGYE medium + $10 \mathrm{mM} \mathrm{NaCl}(\mathrm{pH} 10.5)$

FIGURE 8 | Thematic diagram of the phenotype summaries of the respiratory chain complexes of $\Delta 01690, \Delta c t a D$, and $\Delta F_{0}$. Based on the results depicted in Figures 4A, 7A, the respiratory chain enzymes and ATP synthase of $\Delta 01690, \Delta$ ctaD, and $\Delta F_{0}$ in the KGYE medium plus $5 \mathrm{mM} N a C l$ (pH 10.5$)$ are shown. The $\Delta \mathrm{ctaD}$ strain is a defective mutant of $c_{3} a_{3}$-type terminal oxidase. The $\Delta F_{0}$ strain is a defective mutant of $F_{1} F_{0}$-ATP synthase. A common phenotype of all three strains was the decreased activity of SDH and NDH-II. BpOF4_01690 is shown as a purple structure.

and KMYE medium plus $25 \mathrm{mM} \mathrm{NaCl}$ at $\mathrm{pH} 10.5$ showed similar phenotype except TMPD oxidase activity (Figure 4A, upper right and Figure 4B, upper right). The high $\mathrm{NaCl}$ concentration $(400 \mathrm{mM})$ in the KGYE medium at $\mathrm{pH} 10.5$, the activity of NADH oxidase, TMPD oxidase and ATPase exhibited increased up to $172 \% \pm 17 \%, 139 \% \pm 3 \%$ and $183 \% \pm 8 \%$, respectively, compared with wild type (Figure 4A, bottom right). On the other hand, the activity of succinate 


\section{wild type}

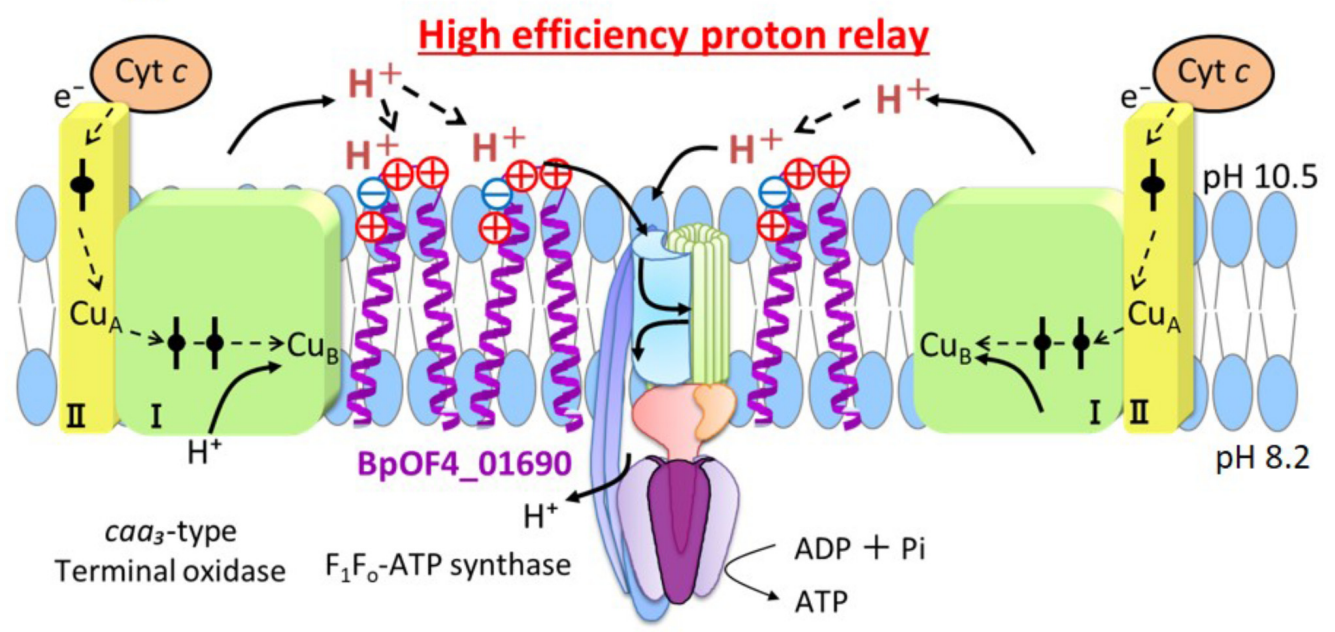

\section{$\Delta 01690$}

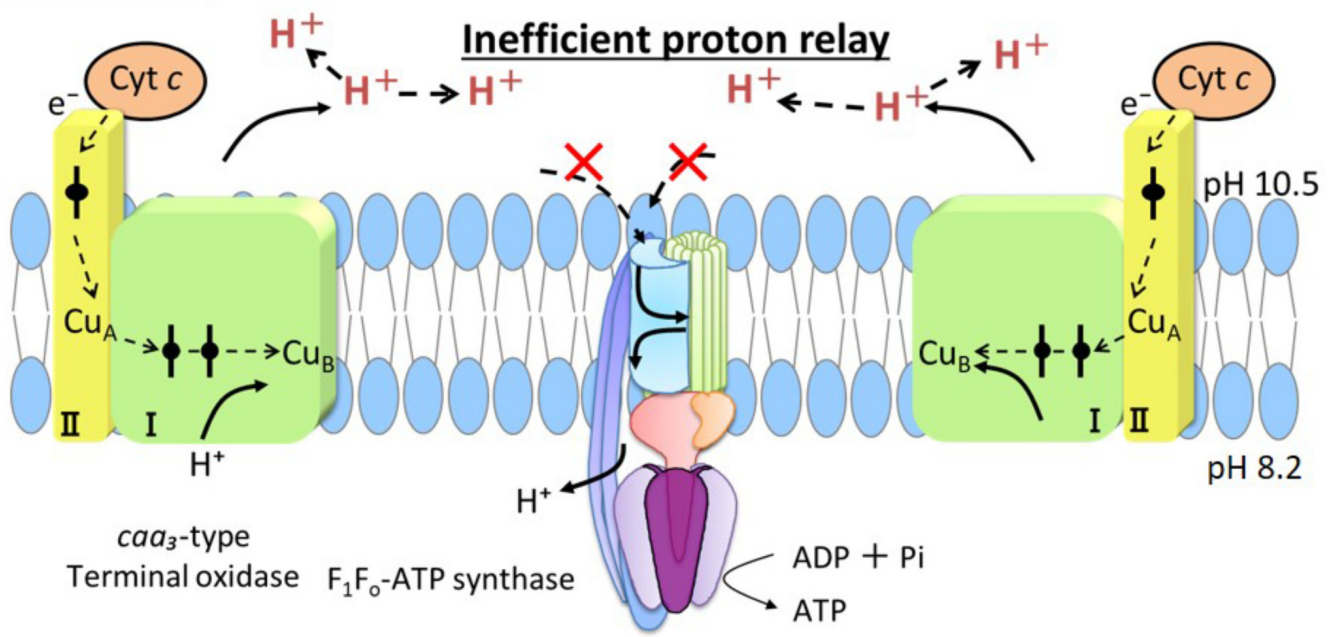

FIGURE 9 | Model diagram of ATP synthesis by OXPHOS in the wild type and $\triangle 01690$ under highly alkaline conditions. In the wild type strain, OXIPHOS is conducted by efficient proton delivery between the respiratory chain and $F_{1} F_{0}$-ATPase due to the presence of BpOF4_01690. In contrast, OXIPHOS does not work

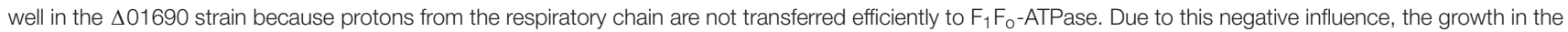
KMYE medium was extremely poor. It is, therefore, inferred that BpOF4_01690 mediates this efficient proton delivery.

dehydrogenase was decreased to $45 \% \pm 1 \%$ compared with wild type. These results suggest that at highly alkaline $\mathrm{pH}$, the protein BpOF4_01690 affects both the respiratory chain and ATP synthesis by OXPHOS.

The expression levels of cytochrome $b c_{1}$ and cytochrome $\mathrm{caa}_{3}$ of everted membrane vesicles prepared from the wild type, $\Delta 01690$, and $\Delta 01690-\mathrm{R}$ in the KGYE and KMYE media with low or high $\mathrm{Na}^{+}$concentrations at $\mathrm{pH} 10.5$ were determined by heme staining and compared (Figure 5). In the KGYE

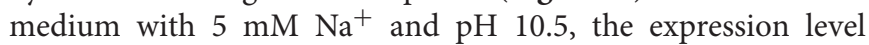
of cytochrome $b c_{1}$ of $\Delta 01690$ was reduced to $68 \% \pm 2 \%$ of that of the wild type (Figure 5A). In contrast, in the KGYE medium with $400 \mathrm{mM} \mathrm{Na}^{+}$and $\mathrm{pH} \mathrm{10.5}$, the expression level of cytochrome $\mathrm{Caa}_{3}$ of $\Delta 01690$ increased to $147 \% \pm 32 \%$ of that of the wild type (Figure 5A). However, under an identical condition, there was no indication that the growth of $\Delta 01690$ was more intensive than that of the wild type (Figure 3A, bottom). In the KMYE medium with $25 \mathrm{mM} \mathrm{Na}^{+}$ and $\mathrm{pH}$ 10.5, the expression levels of cytochrome $\mathrm{caa}_{3}$ and cytochrome $b c_{1}$ of $\Delta 01690$ were reduced up to $70 \% \pm 4 \%$ and $69 \% \pm 3 \%$ of those of the wild type, respectively (Figure 5B). In contrast, in the KMYE medium with $400 \mathrm{mM}$ 
$\mathrm{Na}^{+}$and $\mathrm{pH}$ 10.5, the expression level of cytochrome $b c_{1}$ of $\Delta 01690$ decreased to $49 \% \pm 0 \%$ of that of the wild type (Figure 5B). These findings suggest that the deletion of BpOF4_01690 negatively affects the expression level of cytochrome $\mathrm{Caa}_{3}$ in the KMYE medium with a low $\mathrm{Na}^{+}$ concentration and high $\mathrm{pH}$; the expression level of cytochrome $b c_{1}$ under all tested conditions was also influenced at high $\mathrm{pH}$, except in the KGYE medium with $400 \mathrm{mM} \mathrm{Na}^{+}$at $\mathrm{pH} 10.5$.

\section{Growth of Strains $\Delta c t a D$ and $\Delta F_{0}$ Mutants Under Low-Sodium Conditions}

To compare the phenotype of $\Delta 01690$ with other respiratory chain and OXPHOS-related mutants, the $\triangle c t a D$ mutant in which disruption was caused in the $c t a D$ of $c a a_{3}$-type terminal oxidase operon and the $\Delta \mathrm{F}_{\mathrm{o}}$ mutant with the deleted $\mathrm{F}_{\mathrm{o}}$ part (atpB-F) of unc operon were used as reference and comparative strains. The growth of the wild type and these two mutants was measured in the KGYE and KMYE media at pH 7.5 and 10.5 (Figure 6).

The growth of the wild type, $\Delta c t a D$, and $\Delta \mathrm{F}_{\mathrm{o}}$ in the KGYE medium at $\mathrm{pH} 7.5$ and 10.5, was compared as a function of $\mathrm{NaCl}$ concentration (Figure 6A). The wild type had optimal growth at $25-400 \mathrm{mM} \mathrm{NaCl}$ at $\mathrm{pH} 7.5$ and at $5-400 \mathrm{mM}$ $\mathrm{NaCl}$ at $\mathrm{pH} 10.5$, whereas both $\Delta c t a D$ and $\Delta \mathrm{F}_{\mathrm{o}}$ mutants had a significantly lower level of growth at $10 \mathrm{mM} \mathrm{NaCl}$ at $\mathrm{pH} 10.5$ (Figure 6A). The poor growth of both $\Delta$ ctaD and $\Delta \mathrm{F}_{\mathrm{O}}$ mutants was observed in the KGYE medium with $5 \mathrm{mM} \mathrm{NaCl}$ and $\mathrm{pH} 10.5$ and compared to that of the wild type (Figure 6A). Meanwhile, the growth of both $\Delta c t a D$ and $\Delta \mathrm{F}_{\mathrm{o}}$ mutants in the KMYE medium at both $\mathrm{pH}$ values was poor under all examined conditions, even at concentrations above $25 \mathrm{mM} \mathrm{Na}{ }^{+}$, in which the wild type grew actively (Figure 6B).

\section{Measurements of Various Respiratory Chain Activities and Expression Levels of Cytochrome $b c_{1}$ of $\Delta c t a D$ and $\Delta F_{0}$ Mutants}

Measurements were performed of the activities of various respiratory chain complexes and the expression levels of cytochrome $b c_{1}$ of the wild type, $\Delta c t a D$, and $\Delta \mathrm{F}_{\mathrm{o}}$ in the KGYE medium with $400 \mathrm{mM} \mathrm{Na}^{+}$and $\mathrm{pH} 10.5$ (Figure 7A), followed by comparative assessments. The enzymatic activity of NADH oxidase, NADH-ferricyanide reductase, succinate dehydrogenase, and TMPD oxidase, as well as the expression level of cytochrome $b c_{1}$ in $\Delta c t a D$, were lower than those of the wild type. In particular, the activity of TMPD oxidase was hardly detected. In contrast, the ATP hydrolysis activity of $\triangle c t a D$ was almost identical to that of the wild type.

For strain $\Delta \mathrm{F}_{\mathrm{o}}$, the enzymatic activities of NADH-ferricyanide reductase, succinate dehydrogenase, and ATPase were lower than those of the wild type. In particular, the ATPase activity was drastically reduced. In contrast, the enzymatic activity of NADH oxidase and TMPD oxidase, as well as the expression level of cytochrome $b c_{1}$, were almost identical to those of the wild type.

The expression level of cytochrome $b c_{1}$ of $\Delta c t a D$ and $\Delta \mathrm{F}_{\mathrm{o}}$ mutants, one of the terminal oxidases indicated that the $\triangle c t a D$ mutant was much lower in activity compared with the wild type and the $\Delta \mathrm{F}_{\mathrm{O}}$, which showed little activity loss (Figure 7B).

We presumed that $\Delta c t a D$ influences the activities of multiple enzymes of the respiratory electron transport system. In contrast, $\Delta \mathrm{F}_{\mathrm{o}}$ displayed poor ATPase activity and reduced levels of both NADH dehydrogenase and succinate dehydrogenase. The levels of $\Delta c t a D$ and $\Delta \mathrm{F}_{\mathrm{o}}$ were indirectly influenced by the actions of multiple enzymes of the respiratory electron transport system. A thematic diagram of the phenotypes of the respiratory chain complexes of $\Delta 01690, \Delta c t a D$, and $\Delta \mathrm{F}_{\mathrm{o}}$ at high $\mathrm{pH}$ is illustrated in Figure 8. Importantly, a deletion of either $\Delta c t a D$ or $\Delta \mathrm{F}_{\mathrm{o}}$ reduced the expression of the electron transfer enzymes, SDH and NDH-II. Moreover, the deletion of $c t a D$ also led to the loss of $c a a_{3}$-type terminal oxidase activity.

In view of the observations recorded above, similarly to $\Delta c t a D$ and $\Delta \mathrm{F}_{\mathrm{o}}$ mutants, the negative effect of the enzymatic activity of respiratory chain complexes of $\Delta 01690$ might have been due to independently exerted effects that directly influenced the $c a a_{3}$-type terminal oxidase or $\mathrm{F}_{1} \mathrm{~F}_{\mathrm{O}^{-}}$ ATP synthase (Figure 8). Therefore, we suggest that the deletion of BpOF4_01690 influences the activity of the respiratory chain-related enzymes and ATP synthesis by OXPHOS. Moreover, the small protein BpOF4_01690 may also play a critical role under lower sodium motive force conditions.

Highly conserved charged amino acid residues are present in the loop region between the transmembrane segments of BpOF4_01690 and its homologous proteins. Thus, we hypothesize that the negatively charged amino acid residue BpOF4_01690-E21 has a functionally critical role in the surrounding conserved positively charged amino acid residues (Figure 2B). We propose a working model describing the function of BpOF4_01690 (Figure 9). Some of the protons effluxed from the proton pump of the respiratory chain bind to negatively charged sites of the side chain of the glutamic acid residue of BpOF4_01690 at the outer surface of the cell membrane. Then, the protons are efficiently transferred to $\mathrm{F}_{1} \mathrm{~F}_{\mathrm{o}^{-}}$ ATP synthase, which is present in the proton pump of the terminal oxidase and BpOF4_01690 in the vicinity of a highly alkaline environment.

\section{CONCLUSION}

In conclusion, the small protein BpOF4_01690 appears to play a central role in the energy-coupled retention of protons needed for ATP synthesis via OXPHOS of alkaliphilic Bacillus species in highly alkaline environments. This finding is very interesting while considering that alkaliphiles acquired BpOF4_01690 in the process of evolution to adapt to OXPHOS in alkaline environment. 


\section{AUTHOR CONTRIBUTIONS}

TK and MI designed the research. TT performed the research with experimental work. TT, TK, and MI analyzed the data. TK and MI wrote the paper.

\section{FUNDING}

This work was supported in part by research grant GM28454 from the National Institute of General Medical Sciences (to TK) as well as a grant from Bio-Nano Electronics Research Centre, Toyo University (to MI).

\section{REFERENCES}

Aono, R., Hayakawa, A., Hashimoto, M., Kaneko, H., Nakamura, S., and Horikoshi, K. (1993). Cloning of a gene required for the alkaliphily of alkaliphilic Bacillus sp. strain C-125. Nucleic Acids Symp. Ser. 29, 139-140.

Chen, Y. C., Taylor, E. B., Dephoure, N., Heo, J. M., Tonhato, A., Papandreou, I., et al. (2012). Identification of a protein mediating respiratory supercomplex stability. Cell Metab. 15, 348-360. doi: 10.1016/j.cmet.2012.02.006

Cherepanov, D. A., Feniouk, B. A., Junge, W., and Mulkidjanian, A. Y. (2003). Low dielectric permittivity of water at the membrane interface: effect on the energy coupling mechanism in biological membranes. Biophys. J. 85, 1307-1316. doi: 10.1016/S0006-3495(03)74565-2

Clejan, S., Guffanti, A. A., Cohen, M. A., and Krulwich, T. A. (1989). Mutation of Bacillus firmus OF4 to duramycin resistance results in substantial replacement of membrane lipid phosphatidylethanolamine by its plasmalogen form. J. Bacteriol. 171, 1744-1746. doi: 10.1128/jb.171.3.1744-1746.1989

Fujisawa, M., Fackelmayer, O. J., Liu, J., Krulwich, T. A., and Hicks, D. B. (2010). The ATP synthase a-subunit of extreme alkaliphiles is a distinct variant: mutations in the critical alkaliphile-specific residue Lys-180 and other residues that support alkaliphile oxidative phosphorylation. J. Biol. Chem. 285, 32105-32115. doi: 10.1074/jbc.M110.165084

Guffanti, A. A., and Krulwich, T. A. (1994). Oxidative phosphorylation by ADP + Pi-loaded membrane vesicles of alkaliphilic Bacillus firmus OF4. J. Biol. Chem. 269, 21576-21582.

Guikema, J. A., and Sherman, L. A. (1981). Electrophoretic profiles of cyanobacterial membrane polypeptides showing heme-dependent peroxidase activity. Biochim. Biophys. Acta 637, 189-201. doi: 10.1016/0005-2728(81) 90157-2

Hatefi, Y. (1978). Resolution of complex II and isolation of succinate dehydrogenase (EC 1.3.99.1). Methods Enzymol. 53, 27-35. doi: 10.1016/S00766879(78)53009-7

Hobbs, E. C., Fontaine, F., Yin, X., and Storz, G. (2011). An expanding universe of small proteins. Curr. Opin. Microbiol. 14, 167-173. doi: 10.1016/j.mib.2011. 01.007

Horikoshi, K. (1991). Microorganisms in Alkaline Environments. New York, NY: VCH Publishers Inc.

Ito, M., Guffanti, A. A., Zemsky, J., Ivey, D. M., and Krulwich, T. A. (1997). Role of the nhaC-encoded $\mathrm{Na}^{+} / \mathrm{H}^{+}$antiporter of alkaliphilic Bacillus firmus OF4. J. Bacteriol. 179, 3851-3857. doi: 10.1128/jb.179.12.3851-3857. 1997

Ito, M., Hicks, D. B., Henkin, T. M., Guffanti, A. A., Powers, B., Zvi, L., et al. (2004a). MotPS is the stator-force generator for motility of alkaliphilic Bacillus and its homologue is a second functional Mot in Bacillus subtilis. Mol. Microbiol. 53, 1035-1049. doi: 10.1111/j.1365-2958.2004.04173.x

Ito, M., Xu, H., Guffanti, A. A., Wei, Y., Zvi, L., Clapham, D. E., et al. (2004b). The voltage-gated $\mathrm{Na}^{+}$channel NavBP has a role in motility, chemotaxis, and $\mathrm{pH}$ homeostasis of an alkaliphilic Bacillus. Proc. Natl. Acad. Sci. U.S.A. 101, 10566-10571. doi: 10.1073/pnas.0402692101

Ito, M., Morino, M., and Krulwich, T. A. (2017). Mrp antiporters have important roles in diverse bacteria and Archaea. Front. Microbiol. 8:2325. doi: 10.3389/ fmicb. 2017.02325

\section{ACKNOWLEDGMENTS}

We thank Dr. David B. Hicks of Icahn School of Medicine at Mount Sinai and Ms. Yuko Nakano of Graduate School of Life Sciences, Toyo University for technical assistance and Dr. Arthur A. Guffanti for critical reading of the manuscript.

\section{SUPPLEMENTARY MATERIAL}

The Supplementary Material for this article can be found online at: https://www.frontiersin.org/articles/10.3389/fmicb. 2018.01994/full\#supplementary-material

Janto, B., Ahmed, A., Ito, M., Liu, J., Hicks, D. B., Pagni, S., et al. (2011). Genome of alkaliphilic Bacillus pseudofirmus OF4 reveals adaptations that support the ability to grow in an external $\mathrm{pH}$ range from 7.5 to 11.4. Environ. Microbiol. 13, 3289-3309. doi: 10.1111/j.1462-2920.2011.02591.x

Krulwich, T. A. (1995). Alkaliphiles: 'basic' molecular problems of $\mathrm{pH}$ tolerance and bioenergetics. Mol. Microbiol. 15, 403-410. doi: 10.1111/j.1365-2958.1995. tb02253.x

Krulwich, T. A., and Ito, M. (2013). "Prokaryotic alkaliphiles," in The Prokaryotes, 4th Edn, eds E. Rosenberg, E. F. Delong, F. Thompson, S. Lory, and E. Stackebrandt (New York, NY: Springer), 441-469. doi: 10.1007/978-3-64230123-0_58

Krulwich, T. A., Liu, J., Morino, M., Fujisawa, M., Ito, M., and Hicks, D. B. (2011). "Adaptive mechanisms of extreme alkaliphiles," in Extremophiles Handbook, ed. K. Horikoshi (Berlin: Springer), 119-139. doi: 10.1007/978-4-431-53898-1_7

Lebel, D., Poirier, G. G., and Beaudoin, A. R. (1978). A convenient method for the ATPase assay. Anal. Biochem. 85, 86-89. doi: 10.1016/0003-2697(78)90277-4

Liu, J., Fujisawa, M., Hicks, D. B., and Krulwich, T. A. (2009). Characterization of the functionally critical AXAXAXA and PXXEXXP motifs of the ATP synthase c-subunit from an alkaliphilic Bacillus. J. Biol. Chem. 284, 8714-8725. doi: 10.1074/jbc.M808738200

Liu, J., Hicks, D. B., and Krulwich, T. A. (2013). Roles of AtpI and two YidC-type proteins from alkaliphilic Bacillus pseudofirmus OF4 in ATP synthase assembly and nonfermentative growth. J. Bacteriol. 195, 220-230. doi: 10.1128/JB. 01493-12

Liu, J., Ryabichko, S., Bogdanov, M., Fackelmayer, O. J., Dowhan, W., and Krulwich, T. A. (2014). Cardiolipin is dispensable for oxidative phosphorylation and non-fermentative growth of alkaliphilic Bacillus pseudofirmus OF4. J. Biol. Chem. 289, 2960-2971. doi: 10.1074/jbc.M113.536193

Liu, X., Gong, X., Hicks, D. B., Krulwich, T. A., Yu, L., and Yu, C. A. (2007). Interaction between cytochrome caa3 and F1F0-ATP synthase of alkaliphilic Bacillus pseudofirmus OF4 is demonstrated by saturation transfer electron paramagnetic resonance and differential scanning calorimetry assays. Biochemistry 46, 306-313. doi: 10.1021/bi0619167

Lowry, O. H., Rosebrough, N. J., Farr, A. L., and Randall, R. J. (1951). Protein measurement with the Folin phenol reagent. J. Biol. Chem. 193, 265-275.

Morino, M., Natsui, S., Swartz, T. H., Krulwich, T. A., and Ito, M. (2008). Single gene deletions of $m r p A$ to $m r p G$ and $m r p E$ point mutations affect activity of the $\mathrm{Mrp} \mathrm{Na}{ }^{+} / \mathrm{H}^{+}$antiporter of alkaliphilic Bacillus and formation of hetero-oligomeric Mrp complexes. J. Bacteriol. 190, 4162-4172. doi: 10.1128/JB. 00294-08

Morino, M., Ogoda, S., Krulwich, T. A., and Ito, M. (2017). Differences in the phenotypic effects of mutations in homologous MrpA and MrpD subunits of the multi-subunit Mrp-type $\mathrm{Na}\left({ }^{+}\right) / \mathrm{H}\left({ }^{+}\right)$antiporter. Extremophiles 21, 51-64. doi: $10.1007 / \mathrm{s} 00792-016-0877-\mathrm{z}$

Mulkidjanian, A. Y. (2006). Proton in the well and through the desolvation barrier. Biochim. Biophys. Acta 1757, 415-427. doi: 10.1016/j.bbabio.2006. 04.023

Preiss, L., Hicks, D. B., Suzuki, S., Meier, T., and Krulwich, T. A. (2015). Alkaliphilic bacteria with impact on industrial applications, concepts of early life forms, and bioenergetics of ATP synthesis. Front. Bioeng. Biotechnol. 3:75. doi: 10.3389/ fbioe. 2015.00075 
Sakamoto, J., Matsumoto, A., Oobuchi, K., and Sone, N. (1996). Cytochrome bd-type quinol oxidase in a mutant of Bacillus stearothermophilus deficient in caa3-type cytochrome c oxidase. FEMS Microbiol. Lett. 143, 151-158. doi: 10.1111/j.1574-6968.1996.tb08474.x

Schagger, H., and Von Jagow, G. (1987). Tricine-sodium dodecyl sulfatepolyacrylamide gel electrophoresis for the separation of proteins in the range from 1 to $100 \mathrm{kDa}$. Anal. Biochem. 166, 368-379. doi: 10.1016/0003-2697(87) 90587-2

Storz, G., Wolf, Y. I., and Ramamurthi, K. S. (2014). Small proteins can no longer be ignored. Annu. Rev. Biochem. 83, 753-777. doi: 10.1146/annurev-biochem070611-102400

Su, M., Ling, Y., Yu, J., Wu, J., and Xiao, J. (2013). Small proteins: untapped area of potential biological importance. Front. Genet. 4:286. doi: 10.3389/fgene.2013. 00286

Swartz, T. H., Ito, M., Ohira, T., Natsui, S., Hicks, D. B., and Krulwich, T. A. (2007). Catalytic properties of Staphylococcus aureus and Bacillus members of the secondary cation/proton antiporter-3 (Mrp) family are revealed by an optimized assay in an Escherichia coli host. J. Bacteriol. 189, 3081-3090. doi: 10.1128/JB.00021-07

Terahara, N., Sano, M., and Ito, M. (2012). A Bacillus flagellar motor that can use both $\mathrm{Na}^{+}$and $\mathrm{K}^{+}$as a coupling ion is converted by a single mutation to use only $\mathrm{Na}^{+}$. PLoS One 7:e46248. doi: 10.1371/journal.pone.0046248
Wang, Z., Hicks, D. B., Guffanti, A. A., Baldwin, K., and Krulwich, T. A. (2004). Replacement of amino acid sequence features of a- and c-subunits of ATP synthases of alkaliphilic Bacillus with the Bacillus consensus sequence results in defective oxidative phosphorylation and non-fermentative growth at $\mathrm{pH}$ 10.5. J. Biol. Chem. 279, 26546-26554. doi: 10.1074/jbc.M401 206200

Yoshimune, K., Morimoto, H., Hirano, Y., Sakamoto, J., Matsuyama, H., and Yumoto, I. (2010). The obligate alkaliphile Bacillus clarkii K24-1U retains extruded protons at the beginning of respiration. J. Bioenerg. Biomembr. 42, 111-116. doi: 10.1007/s10863-010-9278-7

Conflict of Interest Statement: The authors declare that the research was conducted in the absence of any commercial or financial relationships that could be construed as a potential conflict of interest.

Copyright (c) 2018 Takahashi, Krulwich and Ito. This is an open-access article distributed under the terms of the Creative Commons Attribution License (CC BY). The use, distribution or reproduction in other forums is permitted, provided the original author(s) and the copyright owner(s) are credited and that the original publication in this journal is cited, in accordance with accepted academic practice. No use, distribution or reproduction is permitted which does not comply with these terms. 